\title{
FROM A TOKOTOKO: PACIFIC TRAVELS WITH PROFESSOR ANGELO
}

\section{Andrew Townend *}

A central stream of Professor Tony Angelo's work over many years has been his contribution to legal and constitutional development in the Pacific. Many countries and many individuals have benefited from his input and experience, as an advisor to government and lawmakers, as a teacher, as a "legislative gardener" helping to keep the statute book in order, and as a sounding-board and mentor. He has made an enormous contribution to Tokelau in particular, working to assist the development of a modern legal system that reflects the special characteristics of the country and its people.

From early 2002 to mid-2004 I was privileged to work as a research assistant to Professor Angelo, accompanying him on several trips to Tokelau, as well as to the Marshall Islands and Niue. He had been my supervisor for an Honours essay in $2001,{ }^{1}$ and I had seen then what a hive of activity his office was and what a variety of projects he and his team were undertaking. When in late 2001 he asked if I would be interested in doing some work for him alongside my studies, I jumped at the chance. Much of the work initially involved editing manuscripts on comparative and private international law. Another enjoyable aspect was preparing Niuean and Tokelauan laws for publication, a traditional task of Professor Angelo's research assistants.

I finished my studies in mid-2003, and in July of that year had my first overseas trip with Professor Angelo, to Majuro, capital of the Republic of the Marshall Islands. Professor Angelo had been commissioned by the International Telecommunication Union to draft a new telecommunications statute for the Marshalls, separating the two functions of regulation and service delivery. While the idea was simple enough, there was little appetite for it on the ground, even within the Telecommunications Ministry - a point illustrated a year later when our main interlocutor, the Ministry's Director of Communications, left to become General Manager of the monopoly service provider, the National Telecommunications Authority. Our work was further

* The author works for the Ministry of Foreign Affairs and Trade, and is currently posted at the New Zealand Embassy in Berlin. He has written this article in his personal capacity and not as an official of the Ministry.

1 Andrew Townend "The Strange Death of the Realm of New Zealand: The Implications of a New Zealand Republic for the Cook Islands and Niue" (2003) 34 VUWLR 571. 
complicated by the difficulties of locating relevant existing laws, and of tracking down people who might know where to find them. Even the parliament itself had no complete collection - a problem by no means confined to the Marshalls.

After a somewhat frustrating few days we had a difficult time getting home again. Flights to and from the Marshalls are infrequent, and a delayed departure out of Majuro to Honolulu meant missing our onward flight to Auckland. Professor Angelo had urgent business back in Wellington, including his investiture as a Knight of the Academic Palms, ${ }^{2}$ and after running around various airline offices managed to get out of Honolulu on the last seat of a Polynesian Airlines service. I ended up waiting a further three days at the Honolulu Airport Hotel (no place for an extended stay), nursing an increasingly debilitating stomach bug. All things considered, it had been an unpromising first trip. But there were great things to come, particularly on the Tokelau front.

Professor Angelo's connection with Tokelau goes back to the early 1980s, when he was engaged by the New Zealand Ministry of Foreign Affairs to review the law of the territory, including its publication and future development. Just finding the law in the first place was not easy: Professor Angelo's first report on the project notes that the sources of Tokelauan law then included not only New Zealand statutes (most importantly, the Tokelau Act 1948) and regulations made by New Zealand under the Tokelau Act, but also delegated legislation from the period 1916-1926 (when Tokelau was part of the Gilbert and Ellice Islands Colony), as well as the statute and common law of England as at 14 January 1840 so far as not inconsistent with the Tokelau Act and not inapplicable to the circumstances of Tokelau. Determining quite what that last category included was politely described by Professor Angelo as "a task of some complexity". ${ }^{3}$

By mid-2003, what had started as a technical legislative review had evolved into a process of development of all aspects of the Tokelauan legal system. In 1996 Tokelau's national assembly, the General Fono, had been given the power to enact legislation in the form of Rules, ${ }^{4}$ and this power was increasingly being used to patriate laws originally made by New Zealand. Furthermore, consideration was increasingly being given to the future constitutional status of Tokelau. Tokelau is a non-self-governing territory under Article 73 of the Charter of the United Nations, and New

2 Professor Angelo was appointed a Knight in the French Order of the Academic Palms in August 2003, in recognition of his longstanding collaboration with the University of French Polynesia.

3 A H Angelo Research and Revision of the Law of Tokelau: An Interim Report on Progress (Ministry of Foreign Affairs, Wellington, 1981) 3. The Report goes on at 4 to note the time-consuming nature of the work, given the limited availability and poor physical condition of many of the relevant materials: "[T]o be in a position to make an authoritative statement on the relevant legislation it has been necessary to read many volumes of documents to find what has been a very small quantity of legislation". See also A $\mathrm{H}$ Angelo Research and Revision of the Law of Tokelau: Second Report (Ministry of Foreign Affairs, Wellington, 1984), setting out a comprehensive overview of the Tokelau legal system as it then stood.

4 Tokelau Amendment Act 1996. 
Zealand, as its administering power, is under an obligation to develop self-government there. Of the various options for self-government, free association with New Zealand (a status similar to that of the Cook Islands and Niue) was emerging as the one most suited to Tokelauan circumstances. Alongside the ongoing legislative work of the General Fono, therefore, discussions were underway on the development of a self-government Constitution and a Treaty of Free Association with New Zealand. $^{5}$

From mid-2003 onwards, these discussions followed a fairly structured programme. Successive rounds of consultations were held in the villages of Tokelau, led by Tokelau's two government lawyers with guidance from Professor Angelo in Wellington. And at the end of each year, the General Fono met to consider the results of the consultations, before formally adopting proposals as Rules or resolutions. There were also periodic meetings of Tokelau's national executive body, the Council for Ongoing Government, including on the negotiation of the Treaty of Free Association. For a recent graduate with an interest in constitutional law this was thrilling stuff, and I was lucky to experience much of it first-hand. A large part of that experience was the journey itself.

The only access to Tokelau is by boat from Apia, Samoa. I remember well arriving in Apia for the first time, in October 2003, and how vibrant and colourful it was, in some contrast to Majuro. We arrived in the evening, and drove from the airport into town through a fragrant haze of smoke from cooking fires. As on other trips, our accommodation was the Insel Fehmarn Hotel, its name a reminder of the German colonial period. ${ }^{6}$ Professor Angelo, who was well used to the tropics and to Tokelauan conditions in particular, travelled light, with a brown leather bag containing a modest selection of trousers and long-sleeved shirts (excellent protection against the harsh Tokelauan sun), as well as a couple of ties for meetings and a white flannel hat. I, on the other hand, had gone for more of a great outdoors approach, with a tramping pack full of clothes and equipment for every climatic and social occasion, most of which I did not actually use.

The sea voyage from Apia to Tokelau takes approximately 30 hours - and sometimes longer, depending on which of the three atolls one is heading to. The atolls are several hours' sailing time from one another, and the ship typically does a round trip, often travelling overnight between them. The journey is a challenge even for the most robust of constitutions, and Professor Angelo, who has done it more times than most, would take a more or less horizontal approach. After some hairy experiences on the first couple of trips - including nearly losing my Therm-a-Rest mattress to a gust

5 On these developments generally see generally Andrew Townend "Tokelau's 2006 Referendum on SelfGovernment" (2007) 5 NZJPIL 121. The current law of Tokelau, in contrast to the situation in 1981, is neatly laid out in two volumes, in Tokelauan and English: see Talei Pasikale and others (eds) Tulafono a Tokelau 2005: Ko he Fakaputuga Mautu o na Tulafono Pahia a Tokelau i te Aho 31 Aukuso 2005 [Tokelauan] Laws of Tokelau 2005: A Consolidated Collection of the Legislation of Tokelau as at 1 February 2005 [English] (Manulele Tokelau, Tokelau, 2005).

6 Fehmarn is an island in the Baltic Sea, part of the German federal state of Schleswig-Holstein. 
of wind - I too came to adopt an approach of essential hibernation, with just the odd barley sugar and periodic cups of tea.

There was always an interesting mixture of people on the boat. As well as locals going to and from the atolls, other travellers included Tokelauan public servants based in Apia, advisers from New Zealand, priests, missionaries, Volunteer Service Abroad workers, doctors (often German), and representatives of NGOs and international organisations. There was even the occasional adventurous tourist, including on one trip the indomitable Lynn Stephenson of Raleigh, North Carolina - at the time of writing the second-most-travelled woman in the world. ${ }^{7}$

The two main shipping options on the Apia-Tokelau run are the MV Tokelau, owned and operated by the Tokelauan Government, and the Samoan Shipping Corporation's MV Lady Naomi, chartered from time to time. The Lady Naomi, a medium-sized passenger ferry, is relatively comfortable, with a large seating/dining area and good bunk rooms. The MV Tokelau is much smaller and very basic, with only a couple of small cabins, and on the trips I experienced was always heavily loaded with passengers as well as supplies for the villages. I slept on the top deck the first couple of times, wedged in between other passengers, getting wet when it rained, and trying to breathe through my mouth to avoid the diesel fumes that would waft across the deck. In heavy seas both boats would make painfully slow progress, at times seeming to be going barely faster than jogging speed. Worst of all was when the boat rose up to the top of the swell, only to crash down again into the next trough, sending a shudder through the whole ship and the stomachs of those on board.

But spirits always improved as we approached land. There were more and more flying fish and seabirds around, and it was exciting to see the atoll slowly rising up from the horizon as we came nearer. Tokelau has no wharves suitable for large vessels, so passengers and cargo have to be ferried ashore in a low aluminium barge with an outboard motor. This is perhaps the most dangerous part of the journey, as the barge has to be steered in through a channel in the reef, getting the timing right to avoid being caught by the swell. Thankfully we never came to grief during my time, but one always had the feeling that disaster was only a few centimetres away.

My first experience of a Tokelauan village was Fale on Fakaofo. ${ }^{8}$ The trip was slightly longer than expected, as we arrived on a Sunday and had to stay on the boat for several hours until church was finished and the aumaga (able-bodied men) could come out to collect us. But the wait was worth it. In Fale particularly, the transition from the vast open sea to the heart of the village comes very quickly. We walked up the concrete ramp from the wharf, past the village pigs (who famously live on the reef, supplementing their diet with shellfish), and all of a sudden were walking along

7 See www.mosttraveledpeople.com.

8 Fakaofo is unlike the other two atolls, Atafu and Nukunonu, in that the village is in two parts: Fale (the original settlement) and Fenua Fala (site of the school and hospital, and settled in the 1960s). 
immaculate coral paths between the houses, under the shade of breadfruit trees, with chickens on the ground and white terns in the branches above. Villagers greeted us with cries of "Malo!", and after thirty hours on the open sea it felt warm and intimate, like we had walked right into someone's living room. We went to the meeting house, the falefono, to greet the village elders, and were served fresh coconuts, which were especially refreshing after the long trip.

Once the travellers had got unpacked and cleaned up it was down to business. Meetings of the General Fono are solemn occasions, and always begin with a prayer and exchanges of greetings between the hosts and the visitors, like on a marae in New Zealand. When discussion turned to legal matters, Professor Angelo would be invited to address the meeting and introduce the issues under consideration. Interpreting was usually done by the late Falani Aukuso, Tokelau's government secretary. Delegates would ask questions, to which Professor Angelo would give thorough and lucid responses. The high respect in which he is held by the elders of Tokelau was very clear, and in meetings I often heard him referred to as a toeaina or "grey-hair". Falani would also cheerfully refer to him as "te Poloheha" (the Professor).

Professor Angelo's contributions were always based on meticulous preparation. Meeting documents were prepared in advance, to enable the participants to consider the record of their deliberations to date, as well as any new proposals. At the end of each day we would write up the proceedings, and the report of the meeting was always finished by the time we left again for New Zealand. Getting the report printed was not always easy: the humid, salty air (not to mention cyclones) is no friend of paper or electrical equipment.

There wasn't much downtime in all of this. I particularly remember a weekend in November 2003 when Professor Angelo and I sat at Matamatagi, the village guest-house in Fakaofo, pulling together the main elements of Tokelau's existing constitutional law into a single consolidated text. The resulting document was structured in the form of a constitution, and came to be known as the "Second Glimpse" of a Constitution for Tokelau. ${ }^{9}$ It included the Standing Orders of the General Fono, as well as applicable provisions of the Tokelau Act 1948 and the Constitution Act 1986. I rather let the side down in not having a copy of the Constitution Act on hand, but we managed to contact a colleague at the Law School in Wellington and have her read relevant provisions over the phone.

When the work was done - and we were a pretty efficient team - there were swims in the lagoon and outings to other islets. The absolute highlight for me was a visit with Falani and others to Fenua Loa, an islet at the southern tip of Fakaofo. The islet has its own lagoon, surrounded by tall trees and lush undergrowth, and fed at high tides by a narrow channel to the sea. The water is an intense

9 See "Vainiuga o Kalelega: Report on the Constitution and Lawmaking Sessions of the General Fono: Fakaofo, 17-21 November 2003" 13-20. For the First Glimpse, see "Tokelau: Elements of the Constitution" (1997). 
bright green and wonderful to swim in. We left our return home quite late, and motored slowly back between the coral heads, with Mars and Venus overhead and the wide open sky getting steadily darker.

Another memorable occasion was night fishing off the reef at Fenua Fala with Falani, Matulino Iosefo and another friend of his in an aluminium dinghy. We baited our hooks with octopus and dropped them over the side, with the line in one hand and a Vailima beer in the other. I caught the first fish, a small eve. Matulino then brought up the rather stunned front half of another, somewhat bigger fish, and shortly thereafter I felt a strong pull on my line: a small shark that had presumably just bitten off the back half of the previous catch. With the others encouraging me on, I did my best to pull the thing in, losing my Vailima in the process. Once I'd brought it in close enough to confirm that it in fact was a shark, Matulino's friend took over my line, pulled the shark up against the side of the boat, and proceeded to dispatch it with a series of blows to the head with a piece of four-bytwo.

By this stage I was getting quite keen on these Pacific adventures, and shortly before Christmas 2003 Professor Angelo and I went to Niue. Getting there was a breeze in comparison to Tokelau: Niue has an airport, and can usually be reached by a direct flight from Auckland. What struck me on first arrival was how much more developed it was than Tokelau, with roads and cars and shops. At the same time, it was a very quiet place. Niue's population is comparable to that of Tokelau (approximately 1500) but the living space considerably larger. When driving through the interior one has the impression of being in a vast tropical garden.

For some years Professor Angelo has been engaged in reviewing and reforming the laws of Niue, as well as advising the Government of Niue on other constitutional and legal matters. On the assumption of self-government in 1974, Niue inherited a large amount of New Zealand legislation. It had full power to amend it, but there was never any systematic clean-up of the books. By 2003 the statute law of Niue was a very overgrown garden indeed - a shambolic mixture of redundant New Zealand laws, others that were still relevant but never adapted to suit Niue beyond essential surgery in 1974, and a fair number of statutes made by Niue since self-government with varying degrees of coherence. This presented huge problems of accessibility - assuming one had even found the current law in the first place. Professor Angelo had published a complete collection in 1990, supplemented by periodic updates, but copies were few on the island: the Speaker's office, for example, was still using an obsolete 1967 edition of Niuean Ordinances.

As in Tokelau, Professor Angelo demonstrated extraordinary stamina, working hard on the basis of very little sleep. One evening we sat late into the night in his room in the Niue Hotel preparing a Bill to clean up the Niue Act 1966 and other Niuean statutes, with Professor Angelo dictating from his hand-annotated copy of the 1990 collection and me doing the typing. This was a privilege that no other research assistants will get to enjoy - not least because two weeks after our departure the Niue Hotel was destroyed by Cyclone Heta. The Bill became the Legislation (Correction of Errors and Minor Amendments) Act 2004: 37 pages' worth of amendments "to remove from Niue 
legislation laws which conflict with the Constitution, to repeal laws that are obsolete or irrelevant to the contemporary situation of Niue, to correct errors in the laws, to provide a suitable basis for an up-to-date reprint of Niue laws, and generally to make the law more accessible and appropriate to Niue circumstances". ${ }^{10}$ Despite the unglamorous subject-matter, Professor Angelo, fuelled by several cups of black tea, showed no signs of tiring, and it was not until his typist finally ground to a halt that work was suspended - only to be continued the following day during an unexpected delay at Faleolo airport in Samoa.

In early 2004 I started work in the Legal Division of the Ministry of Foreign Affairs and Trade. But while my employer had changed, the subject matter was the same: Pacific legal issues, and in particular the development of self-government in Tokelau. The experience I had gained working for Professor Angelo was invaluable for my new position, and I very much appreciated our ongoing contact. In May 2004 I attended a United Nations decolonisation seminar in Madang, Papua New Guinea, and delivered a paper on Professor Angelo's behalf. Falani Aukuso introduced me to the meeting as Professor Angelo's tokotoko. The word literally means "walking stick", so the image is of a supporter to a learned elder - though anyone who has seen Professor Angelo on the dance-floor of a Tokelauan falefono will question its aptness. Some weeks later Professor Angelo and I went again to Niue to continue work on the law project. And there were further trips to Tokelau for meetings of the General Fono in October 2004, and then through 2005 leading up to the first referendum on selfgovernment, in February 2006.

Throughout my work for and with Professor Angelo I appreciated his sustained good humour and remarkable generosity. He has been a mentor for numerous research assistants in Wellington, and for young lawyers in the Pacific, who are always few in number and often work with minimal local support. He has helped to bring consistency to legislation and ensured the maintenance of the legal record in environments where lawmaking is an often sporadic and unsystematic undertaking. And he is responsible for the development of laws attuned to local circumstances, whether the impetus for those laws is local or comes from outside. The countries of the Pacific to which Professor Angelo has dedicated and continues to dedicate such a large part of his career could not be better served.

10 Legislation (Correction of Errors and Minor Amendments) Act 2004 (Niue) Long Title. See also the Niue Amendment Act 2007 (NZ), which made corresponding amendments to the Niue Act 1966 in its New Zealand form. The amendments were prepared in the Legal Division of the Ministry of Foreign Affairs and Trade, on the basis of a clinical legal studies project done by Talei Pasikale (who has also worked as research assistant to Professor Angelo), and drafted by the Parliamentary Counsel Office. The project also led to the repeal of numerous redundant provisions of the New Zealand version of the Cook Islands Act 1915 (see Cook Islands Amendment Act 2007), and to the amendment of the Tokelau Act 1948 to take account of developments towards self-government (Tokelau Amendment Act 2007). 
